\title{
Legal Politics and Responsibilities of Indonesia's Government in Water Pollution Construction
}

\author{
Dr. H. Joni, SH. MKn, MH. \\ Notary in Sampit and Lecturer at the College of Law, Habaring Hurung Sampit, Central Kalimantan
}

\begin{abstract}
Research on Legal Actions and Responsibilities of the Government of Indonesia in Overcoming Water Pollution, is a normative legal research, by examining various legal aspects relating to the research problem in question. From the research conducted, it provides an understanding that Indonesia is an archipelago whose seas cover two-thirds of its national territory, and has the second longest coastline in the world. Known as a maritime country, it has a huge responsibility to protect its waters from water pollution. For this reason, the regulation of existing environmental law must be integrated and comprehensive. In addition, it is also necessary to apply the principles of cross-national pollution law in legislation that are regulated integratively. However, the rule is only a rule if it is not accompanied by law enforcement. Law Enforcement in dealing with perpetrators of water pollution has a very important role, to cause deterrent effects (ultimum remedium). This needs to be done to bring about the authority of the law, which is expected to bring fundamental changes in people's attitudes to participate in every movement of national development. This meaning was offered by Mochtar Kusumaatmadja who adopted Roscoe Pound's thinking about "law as a tool of socialengering", namely law as a means of engineering society, which encouraged the creation of legislation and jurisprudence. For this reason, the application of appropriate sanctions for perpetrators of water pollution is civil sanctions in the form of compensation, which can later be used as a tool to rehabilitate the environment so that it can return to normal. Because the people who experience the greatest impact in water pollution are the people in the surrounding environment, so that if the environment is not restored, the community will suffer and the perpetrators will not experience the impact.
\end{abstract}

Keywords: Legal Action; Government Responsibilities; Water Pollution

DOI: $10.7176 / J L P G / 87-09$

Publication date:July $31^{\text {st }} 2019$

\section{Background to the Problem}

The quality of water sources throughout Indonesia is in poor condition. Atlas of Status of Indonesian Water Quality In 2015, 68\% of rivers in Indonesia were heavily polluted, $24 \%$ were moderately polluted, $6 \%$ were mild pollutants and only $2 \%$ met good quality status. The data represents 670 sampling points in 83 rivers spread across 33 provinces throughout Indonesia. ${ }^{1}$ At the end of 2016, the water quality index of 34 provinces announced by the Ministry of Environment and Forestry ("KLHK") showed a decrease in index scores compared to 2015 , from a score of 53.1 to $50.79 .^{2}$ If referring to the 2015 Water Quality Status Atlas data, at least 656 of 670 monitoring points are scattered in 83 rivers which are monitored as polluted.

The low quality of water and the massive pollution in Indonesia are problems that are also experienced by several other developing countries along with the increasing industrialization and urbanization. ${ }^{3}$ There are several gaps between best practices in water quality management and practices in developing countries that are inseparable from the institutional challenges commonly faced by developing countries. Among the various common factors mentioned, the weak capacity of the executive body in charge of the environment due to lack of resources and / or political will and weak law enforcement over water quality management regulations are two factors that are often conveyed in various forums. ${ }^{4}$

Water is human life. Humans then use it to sustain life. Practically, in daily life water is used for various needs. Water is also the main thing for agriculture in terms of rice field irrigation, and also for livestock. Water in industry is used besides as part of the production process it is also used as a cooler. In addition, water provides a living habitat for fish and other aquatic animals, besides that it has an important psychological role in terms of

\footnotetext{
${ }^{1}$ Atlas of Status of Indonesian Water Quality, Indonesian Ministry of Environment and Forestry, 2015.

${ }^{2}$ Ministry of Environment and Forestry, Directorate General of Pollution Control and Environmental Damage (December 2016) End of Year Note KLHK 2016: Healthy Environment for the People. The average monitoring results of 833 monitoring points ( 80 deconcentrated rivers and 60 non-deconcentrated rivers) this year were in mild pollutant status (50.79) which was very close to the moderate pollutant limit (49). The index number is as follows: good if $>70$; mild pollution 50-70; moderate pollutant 30-49; blackened 10-29. In this Final Note, the relationship between this index and the quality status has not been explained.

${ }^{3}$ Richard Helmer dan Ivanildo Hespanhol, United Nations Environmental Program, Water Pollution Control - A Guide to the Use of Water Quality Management Principle (London: Thomson Science \& Professional, 1997)

${ }^{4}$ Mohammed Nasimul Islam, Water Resource Management Specialist, Asian Development Bank, "Challenges for Sustainable Water Quality Improvement in Developing Countries," presentation in International Water Week, Stockholm, Sweden, September 8, 2010. "M.C. Mehta vs. Union of India," The Enviro-Litigators, Environmental Law
} 
providing recreational areas as well as natural beauty. In addition, water has a very important role in the process and disposal of waste originating from domestic or industry. Disposal of solid or liquid waste into the water can cause water pollution. Water pollution can occur in various ways. Materials such as domestic sewage, chemicals, detergents are commonly contaminated into the water whether intentional or unintentional. Agriculture is also one of the main causes in water pollution in terms of the use of chemical-based pesticides or fertilizers, in addition to industrial waste, namely residual production in the form of liquid which is discharged through company pipes into public waterways. As a result of water pollution in these waterways it can cause damage or disease to animals and aquatic plants, including humans.

Eradication of water pollution is not easy, this is because in reality many types of waters such as rivers, ponds, lakes and seas have different capacities in absorbing and spreading pollution (water). For example, rivers that have more ability to purify polluted water because of micro-organisms found in rivers in addition to the effects of the sun and aeration of the air, when compared with small ponds (swamps).

Therefore, disposal of waste into rivers within certain limits can still be tolerated. This has led to the tendency to dump waste into rivers which are preferred and considered effective. Because the costs incurred are very cheap, even at no cost. This is a problem in making regulations, the extent to which the prohibition on the disposal of waste into rivers can guarantee the river's ability to absorb and disseminate waste.

In other words, what size is a river polluted by waste. Whereas on the other hand, rivers in general in Indonesia, especially in big cities are providers of drinking water raw materials organized by Regional Water Companies. So that if the river is polluted, it will have a direct impact on human life, so that it is very important in controlling water pollution, especially in rivers. The expected action, of course, is to stop the source of pollution. But that is difficult, because naturally humans will issue waste, therefore controlling the source of pollutants by looking at the ability of rivers or waters to absorb and disperse pollutants is a major issue, which needs to be regulated by regulatory regulators.

Therefore efforts to prevent water pollution directly, or efforts to limit waste disposal, as well as how to clean the waters from waste, as well as sanctions given to poluters, and ensure that action is not repeated and pay for cleaning fees, and also provide compensation for parties who were harmed due to pollution. For this reason, the regulation of sewage into waterways is a matter of concern in controlling water pollution.

Based on the above, it is necessary to analyze the topic of the problem of water resources, especially regarding the Legal Actions and Responsibilities of the Indonesian Government in Overcoming Water Pollution

\section{Aspect of Constitutionality}

This aspect of constitutionality is regulated in Article 33 of the 1945 Constitution of the Unitary State of the Republic of Indonesia (hereinafter abbreviated as UUD 45). Expressed in Article 33 of the 1945 Constitution as follows:

1. The economy is structured as a joint effort based on the principle of kinship.

2. Production branches that are important to the State and which control the livelihood of many people are controlled by the State.

3. Earth, water and natural resources contained therein are controlled by the State and are used for the greatest prosperity of the people.

4. The national economy is organized based on economic democracy with the principle of togetherness, efficiency with justice, sustainability, environmental insight, independence, and by maintaining the balance of progress and unity of the national economy.

5. Further provisions regarding the implementation of this article are regulated in the Law.

Thus, the provisions in Article 33 paragraph (1), (2), (3), (4), and (5) of the 1945 Constitution constitute the basis for both the government responsible for the management of natural resources and the people in the region Indonesia. In this article the basis of economic democracy is stated, production is carried out by all, for all under the leadership or ownership of citizens. Community prosperity as the ultimate goal that must be realized in the management of existing natural resources. The philosophy is that earth and water and the natural wealth contained in the earth are the main points of people's prosperity. Therefore it must be controlled by the state and used as much as possible for the realization of people's prosperity as the main goal.

At the technical level, problems related to the elaboration of natural resources based on the article above include legal facts, social facts and physical facts. These three facts indicate how complex the problems of natural resource management in Indonesia. Especially about natural resources, the complexity is increasingly evident, when the need for water resources (hereinafter abbreviated as SDA) continues to increase on the one hand, while on the other hand the existence of natural resources is increasingly limited.

In more detail, at the social level, the complexity comes from the existence of concrete conditions that exist in society that are related to the following:

1. poverty;

2. still weak law enforcement; 
3. there is an impetus to increase Regional Original Revenue which is based on the spirit of regional autonomy

4. objective conditions that protect and manage the environment do not become a national political agenda,

5. the level of synchronization and the strictness of the rule of law are still low

6. Unclear legal politics that underlie legal policies on natural resource management, especially natural resources.

In a philosophical perspective, as the basis of constitutionality over natural resource management, Based on qualitative analysis in the constructive paradigm, it is recommended that the legal politics of natural resource management as stated in the constitution must be elaborated in the legal umbrella of comprehensive natural resource management, meaning that its values and characteristics must be reflect the character that: (1) pro justice; (2) pro welfare; (3) pro local wisdom; (4) pro-environment.

The field of law in relation to this problem is understood as a second understanding, various interrelated provisions are rules that must be carried out by every citizen when interacting with other legal subjects. Likewise with environmental problems and their implications, especially those related to natural resources, both the implications of the application of regulations and the implications of the interaction process in environmental activities, in this case especially natural resources. ${ }^{1}$

The development of Indonesia's national economic system is affected by the globalization phenomenon that is global so that it also experiences a dilemma situation. This situation ultimately results in the management of Natural Resources, which is also faced with a complicated situation. On the one hand, the ideal of the political law regarding the Right to State (HMN) over natural resources has been regulated in the 1945 Constitution of the Republic of Indonesia, especially in Article 33.

In connection with this, the state should control the important branches of production and control the livelihoods of many people so that the value of social justice should still be an inspiration for legal political construction, as part of the Development of the Indonesian National Law System (PSHNI) in the field of Natural Resources. However, the fact is that the company held by the government, namely the water company in several areas has been privatized with the concession model, for example PAM Jaya which has been privatized to PT Thames and PT Lyonnaise, which incidentally is a foreign company. This is certainly ironic. In fact, natural resources that are very vital are not managed by the state, but have been privatized. Mastery of water resources by private and even foreign sources has occurred and continues to grow. ${ }^{2}$

The above is certainly contrary to the position of water as a social object that controls the livelihood of many people which must be controlled by the state and used as much as possible for the prosperity of the people. Even though the 1945 Constitution of the Republic of Indonesia, especially after the amendment, no longer included explanation as an integral part of the torso, but the juridical construction as stated in the explanation of article 33 before the amendment was important to note.

Affirmed in the Explanation of Article 33 of the 1945 Constitution that: "The economy is based on economic democracy, prosperity for all people. Therefore production branches that are important to the state and which control the livelihood of many people must be controlled by the state. If not, the production will fall into the hands of those in power and people who are much oppressed. Only companies that do not control the livelihood of many people may be in the hands of people ". The meaning is that no one denies the claim that the exploitation of water includes production branches that are important to the state and affect the livelihood of many people. Therefore, the exploitation should also be controlled by a non-private state.

On the other hand the management of Natural Resources in Indonesia is faced with a wave of globalization that has a global economic trend. The global economy tends to attribute the capitalist liberal flow that is not pronatural resource management based on people's needs. Practically this requires the existence of privatization in all aspects of the country's economic life. The manager of Natural Resources leads and tends to and is practiced based on the principle of privatization which is not pro-people.

The original intention of the Indonesian people was to manage the economy of a national especially Natural Resources by using Article 33 as its legal political framework. However, the attribute of globalization in the form of capitalism turned out to have forced Indonesia to obey its intention to create a market economy, for example with privatization.

This effort was taken by the Indonesian government by regulating it in Law No. 7 of 2004 concerning About Water Resources. Especially Article 7, Article 8, Article 9, Article 26, Article 38, Article 40, Article 45, Article 46, Article 47 and Article 49. This provision shows that water management leads to the process of privatization or commercialization. In accordance with Article 33 of the 1945 Constitution, water is one of the natural resources that controls the livelihoods of many people, which should be controlled by the state, not by

\footnotetext{
${ }^{1}$ See: Samsul Wahidin. 2014. Dimensions of the Law on Environmental Protection and Management. Yogyakarta: Student Library. Page. 2

2 For example, it happened in Pongok village, Polanharjo Klaten Sub-district, Central Java, namely PT Tirta Investama whose shares were controlled by Danone. See in Samekto and Suteki. 2015. Building the Politics of Natural Law Based on Indonesian Law. Yogyakarta: Thafa Media. Page 4
} 
individuals and private business entities. ${ }^{1}$

In this setting, the Constitutional Court (MK) abolished the existence of all articles in Law Number 7 Year 2004 concerning Water Resources (SDA) submitted by the central leadership (PP) of Muhammadiyah and friends. Because the law is considered not yet, or even does not guarantee restrictions on water management by the private sector. Such conditions are substantially considered to be contrary to the 1945 Constitution of the Republic of Indonesia. With the cancellation of UUSDA, the Constitutional Court decided to return to Law Number 11 of 1974 concerning Irrigation to prevent a legal vacuum until the establishment of a new Law.

With this reality background, understanding of this departs from the attitude that Natural Resources can still be a reliable factor, in addition to human and technological factors for the prosperity of the Indonesian state. Its justification is based on the fact that in the past the superiority of the state was determined by 3 main factors, namely:

a. Indonesia still has sufficient natural resources to prosper the nation, especially water;

b. The quality of human resources cannot be equated with new industrial countries belonging to the rising up states;

c. The level of technological progress has also not been on par with developed countries, so the management of natural resources, especially water, must be carried out by the State. ${ }^{2}$

In this regard, the decision of the Constitutional Court which removes UUSDA and returns to the Irrigation Law, the consistency of the decision is questionable, is there a denial of its implementation. Is there a spirit of togetherness in water management still in the spirit of togetherness that takes sides with the people. The substance of this matter can be observed in the practice of natural resource management.

\section{Orientative aspects}

That water is one of the basic human needs, both in fulfilling their daily needs or for certain parts of society as a form of respect for their ancestors and beliefs. The water crisis will cause potential conflict at the community level, because water is a limited number of public goods, in addition to having a sacred meaning for certain groups. So it needs a regulation that can guarantee the right to water for the entire community.

The increasing demand for water in the midst of water scarcity has made large (private) companies invest their business in this field. The entry of large companies in water management will benefit the capital owners who are oriented towards seeking maximum profits that will endanger the existence of small communities. In the case of water is a very primary commodity for life, and there should not be a shortage of water due to mismanagement.

The World Bank estimates the potential of the water market to be worth 1 trillion US dollars. ${ }^{3}$ This makes the water business the most profitable industry for investors. ${ }^{4}$ The large potential of the water market has made the World Bank look at Indonesia to invest its capital in the regulation of water regulation. This can be seen from the role of the World Bank which is so significant in terms of ratification of Law Number 7 of 2004 concerning Water Resources which takes a long time because of the attraction of the interests of various parties. In the end, it was won by a foreign power that supported the financial assistance disbursed to Indonesia.

In the context of the Indonesian state, the importance of water as a basic human need that requires guaranteed access for all people is very much realized by the founding fathers in this country. This can be seen from Article 33 paragraph (3) of the 1945 Constitution of the Republic of Indonesia (UUD NKRI 1945) which contains that the earth, water and natural resources contained therein are controlled by the state and are used for the greatest prosperity of the people. The nature of water which has a limited amount of water while the population continues to increase requires the seriousness of the State, in this case the government in handling it, both the problem of allocation, use and regulation of water which continues to increase along with the increase in population and diverse uses.

As stated above, that the regulation regarding water in Article 33 paragraph (3) of the 1945 Constitution of the Republic of Indonesia, the position of the state is an organization held by one or several nations that reside in a certain area. The point is to maintain the laws that apply to them, defend the interests and common prosperity of attacks from outside and carry out the ideals of mutual prosperity, both on the spiritual and material fields.

Countries that adhere to democratic ideals basically fight for the realization of public interests or the res republica. Indonesia as a country in the form of a further republic must establish the contents of the republic

\footnotetext{
${ }^{1}$ The term pro folk in its name refers to the effort to erus develop various recreational activities to build an atmosphere of viability and physical \& spiritual fitness. As the saying goes "in a healthy body \& spirit, a healthy soul of development will develop." The fact is that various activities that lead to the interests of the people must really aim and be carried out consistently for and for the sake of the people.

2 Privatization is often associated with service or industry oriented companies. And applied to any assets, such as land, roads or even water. Privatization tends towards free markets. Oriented to capitalist competition, which its supporters consider will provide more competitive prices to the public. Padasisilaion, privatization is a negative value, because providing important services to the public to the private sector will eliminate public control and only concentrate on disbursing profits as much as possible.

${ }^{3}$ Maude Barlow in Vandhana Shiva.2003. Water Wars: Privatization of Profit and Pollution. Yogyakarta: Insist Press. Page. 100

${ }^{4}$ Ibid. Page 102
} 
according to the nature of its original meaning, namely res republica which means for the public interest. In accordance with the meaning of res republica, state administrators must always be oriented to the public interest.

The existence of a constitution in a country is intended as a rule of play in the process of administering the state. Provisions regarding the guarantee of the right to water for all Indonesian people are affirmed in Article 33 paragraph (3) of the 1945 Constitution of the Republic of Indonesia. State control over water as a national natural resource for the fulfillment of people's welfare. Fulfillment of the welfare of all the people of Indonesia as a manifestation of the struggle of the Indonesian people in escaping from colonialism which has created suffering for the people of Indonesia. Thus it is hoped that the suffering will end and the obligation of the Indonesian people to realize prosperity as a consequence of the agreement of all the people of Indonesia to establish a country called Indonesia.

Guaranteeing the right to water for all Indonesians is a form of welfare. The guarantee of the right to water is an embodiment of fulfilling the human rights of the Indonesian people contained in Article 33 paragraph (3) of the 1945 Constitution of the Republic of Indonesia. The right to control the State in the earth, water and natural resources is a form of social rights. This requires government intervention in its management to realize the prosperity of the people themselves. The provisions in Article 33 paragraph (3) of the 1945 Constitution of the Republic of Indonesia which has a noble goal in providing welfare to its people is a utopia when it is not followed by passion and strong desire to make it happen.

The right to water is a human right that does not come from the state. But the particular ecological context of human existence raises rights to water. Therefore, the entry of the state in water management as a manifestation of the right of control contained in Article 33 paragraph (3) of the 1945 Constitution of the Republic of Indonesia is a form of protection of these human rights so that all people can be protected and cannot be eliminated because rights to water are natural rights.

Thus it is clear that water as a human need is a right that must be fulfilled by the state as a form of recognition of the right to life itself. Therefore, the existence of Article 33 paragraph (3) of the 1945 Constitution of NKRI is philosophically as the incarnation of the 5th Sila Pancasila, namely social justice for all Indonesian people. In this case water as one of the national wealth which is a necessity for the needs of the people, is controlled by the state in the framework of providing justice and welfare for all the people of Indonesia. ${ }^{1}$

The affirmation of the right to water in a constitution and the legislation below is within the framework of providing justice for all the people. Concretely, this is a form of limitation on humans themselves in using water. It may not be used only for the personal interests and interests of certain groups by not paying attention to the interests of others. With this arrangement, justice will be given to all people without discrimination and monopoly by certain people or groups. ${ }^{2}$

In Article 33 paragraph (3) of the 1945 Constitution of the Republic of Indonesia, the regulation of the earth, water and natural resources contained therein as a national wealth must have implications for social welfare. At the level of the Law, the right to control the state of the earth, water and space as stated in Article 2 paragraph (1) UUPA is not in the sense of belonging, but in the sense of giving authority to the state as an organization of power from the Indonesian nation, to the highest level take action in the form of:

1. Regulates and organizes its designation, use, inventory and maintenance.

2. Determine and regulate the rights that can be owned by (part of) the earth, water and space.

3. Determine and regulate legal relations between people and legal actions concerning the earth, water and space. The right to control the country is to carry out management, use of national wealth. This is intended to maximize the potential of natural wealth itself. Thus it is very clear that the right to control the country exists in order to create social justice for all Indonesian people in accordance with the mandate of Article 33 paragraph (3) of the 1945 Constitution of the Republic of Indonesia which aims to realize people's welfare. ${ }^{3}$

Social justice according to Natonegoro is a principle that in the social and economic fields there are similarities, in addition to political similarities. In the social and economic field there are individual freedoms and powers in balance with human nature as social beings, to cultivate and fulfill life's needs, which are in accordance with the absolute characteristics of humans as individuals.

Because free life means the right to live, and the right to live means to accept what is needed, not because there are results of his efforts, but the rights of needs in an absolute sense than humans. The right to life, which must be carried out, can only be carried out if it is fulfilled the needs needed to sustain its life and this need is a right.

The foundation of the thought of the birth of Article 33 of the 1945 Constitution of the Republic of Indonesia is inseparable from the values contained in the society itself, such as helping and joint efforts that

\footnotetext{
${ }^{1}$ Ensiklopesi Indonesia, Volume 4. Jakarta: Van Hoeve. Page. 2348..

${ }^{2}$ Sri Soemantri and Bintan R. Saragih. 1993. Indonesian State Administration in Indonesian Political Life 30 Years to 1945 Constitution of the Republic of Indonesia. Jakarta: Sinar Harapan Library. Page. 101.

${ }^{3}$ Padmo Wahjono. 1984. Indonesian State Administration Problems Today. Jakarta: Ghalia Indonesia. Page.34.
} 
distinguish it from the understanding of capitalism. This is precisely what negates the values that form the basis of life and interactions with others, who continue to live and develop according to the development of the times.

In such conditions, capitalism's understanding of economic management by relying on capital and its means of production is not suitable and is not an interaction pattern especially in the economic field of the Indonesian nation. Because capitalism is basically only to seek maximum profits by not paying attention to the interests of weak people, whose numbers are actually the majority in this country. ${ }^{1}$

In this case, in the understanding of capitalism capital ownership and production tools are only owned by a handful of people. In the context of the Indonesian state, in terms of managing something that becomes the livelihood of many people, it must be mastered as contained in Article 33 paragraph (2) of the 1945 Constitution of the Republic of Indonesia in the framework of social justice. This is to prevent a monopoly by a person or a handful of people so that the role of the state in controlling national wealth is to provide guarantees to all the people which leads to the welfare of all people.

Neoliberalism as the latest development of capitalism is usually used as a designation for some special characteristics of economic policies such as privatization, deregulation and liberalization. The essence of neoliberal political economy is the proposition that economic growth will be optimal if the traffic of goods / services / capital is not controlled by any regulation. Optimization will also be maximized if goods, service capital, are owned / controlled by individuals who will move it for maximum profit goals for individuals. If in classical neoliberalism private ownership is still considered to have a social duty to prosper the whole people, in modern neoliberalism the private property is lost. meaning without any social role except for the accumulation of

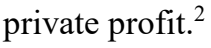

Observing on the principle of the establishment of the neoliberalism above is certainly and even certainly very contrary to the values and philosophy of the Indonesian state. This is evident in the history of the birth of Article 33 of the 1945 Constitution of the Republic of Indonesia NKRI by affirming the role of the government actively in matters relating to the lives of many people, one of which is water. The role of the government here is intended to create social justice. This is to prevent monopoly by a small number of people or groups that can create misery for the people of Indonesia. Water as a public good is the responsibility of the state to guarantee the acquisition and fulfillment of it as a consequence of the control of water by the state as the wealth of the Indonesian nation.

In addition to that, in the understanding of neoliberalism, there is very little uncertainty or the absence of elements of religiosity towards divine values. This can be seen from the glorification of humans as individuals and not based on kinship and mutual cooperation. Of course this is a fundamental contradiction to the values that exist in Indonesian society. For the Indonesian people themselves, the relationship between God, humans and water is inseparable. All three become the basis and existence of life in this world. ${ }^{3}$

The affirmation of this matter can be observed in Article 1 paragraph (2) of the LoGA, that all earth, water and space, including natural resources contained in it within the territory of the Republic of Indonesia as the gift of God Almighty. The position of the earth, water and space of the Indonesian people and is a national wealth that must be managed for mutual prosperity. In developing the mandate for the Indonesian people, the management must be aimed at the development of a prosperous and prosperous Indonesian society. At this point the important meaning of state intervention in the management of all natural resources is needed in order to guarantee the right to obtain results from them which are the basic rights of all Indonesian people.

The linkage of state ownership rights with the greatest prosperity of the people according to Bagir Manan will realize the State's obligations which are basically:

a. All forms of utilization (earth and water) and the results obtained (natural wealth), must significantly improve the prosperity and welfare of the people.

b. Protect and guarantee all people's rights contained in or on earth, water and various natural resources that can be produced directly or enjoyed directly by the people.

c. Prevent any action from any party that will cause the people to not have the opportunity or will lose their opportunity to enjoy natural resources. ${ }^{4}$

In the economic setting, as a basis for management and improvement of welfare, it must be in accordance

\footnotetext{
${ }^{1}$ According to C.F. Strong Democracy is a system of government based on people's agreement. And in a government system that is based on the people's agreement according to F. Sugeng Istanto, there is an understanding that the system of government is intended to protect people's rights, which among them are Human Rights. InF. Sugeng Istanto. 1999. Constitution and Guarantees for Human Rights, Legal Pulpit Journal. Yogyakarta: Faculty of Law, Gadjah Mada University. Page. 67

${ }^{2}$ Ibid. The people's rights in the 1945 Constitution of the Republic of Indonesia, according to F. Sugeng Istanto, cover classic human rights and social rights. What is meant by classical human rights are human rights that demand freedom from government interference so that the government does not act arbitrarily. What is meant by social rights are human rights which demand government intervention.

${ }^{3}$ Vandhana Shiva. Op. Cit. Page. 23.

4 According to JJ Rouseau, there is absolute, natural and holy justice like ours. However, justice has no power because people are corrupt. So conventional justice formulated by law must replace it. JJ. Rouseau. 1989. Regarding Social Contracts or Principles of Political Law, Interpreting: Sundari Husen and Rahayu Hidayat, Jakarta: Dian Rakyat. Page. 38.
} 
with the personality of the Indonesian nation as well. Therefore, an economic system that conforms to Indonesian values according to Mohammad Hatta is a system of cooperative socialism which is then outlined in Article 33 of the 1945 Constitution of the Republic of Indonesia. The system of cooperative socialism contains three important elements, namely: (1) the ideals of western socialism humanity with the implementation of democracy regarding political democracy, (2) Islamic teachings which put forward the basics of justice and brotherhood and a high assessment of personal human beings as creatures of Allah, (3) mutual cooperation as the innate nature of Indonesian society.

From the important fundamental elements above, it can be seen that water management as one of the national assets contained in Article 33 paragraph (3) of the 1945 Constitution of the Republic of Indonesia is very dependent on the values that live within the Indonesian Nation, such as religious values and the value of mutual cooperation. However, Indonesia as a newly independent and developing country does not close itself and is open to values that can support and be in accordance with the development of Indonesian society. The concrete form is the adoption of the ideals of western socialism while still paying attention and maintaining the values and philosophy of the Indonesian nation. Here, the most important thing is how the values that live in Indonesian society have always been the main reference in the policy making process so that it generates populist and participatory policies.

In connection with this water problem, the spirit of water management contained in Law Number 7 of 2004 concerning Water Resources, Water as a vital requirement for people's lives requires regulation in terms of designation and use so that water utilization is expected to be carried out optimally. This is inseparable from the limited nature of water which can cause unrest and conflict in society when guarantees for water are not seriously regulated and are not distributed fairly.

The arrangement of water is not new. This has even begun since Indonesia was not yet independent. This can be traced by holding special provisions for water in Ordantie on 26 September 1936 STB 1936 No 489 concerning Algemeen Water Reglement. This past legal product regulates public waters, water use and building construction based on permits, regarding special obligations in the matter of irrigation and others. As the implementing regulation is Vordening dated 4 October 1937 STB 1937 Number 559 concerning Algemen Water Baheers Verondening.

The arrangement in the next period was the birth of the MPR TAP Number IX / MPR / 2001. In this Decree, the importance of natural resources is reaffirmed as a national wealth in realizing prosperity and justice for the people of Indonesia. This provision mandates optimal management of natural resources, especially water as a form of our gratitude for the natural wealth given by God. This is to realize the noble ideals contained in the opening of the 1945 Constitution of the Republic of Indonesia which demands the seriousness of the government's political commitment in realizing it.

In a more technical arrangement, namely in the Act, the birth of Law Number 7 of 2004 concerning Water Resources that is so long is inseparable from the substance of the Law which gives concessions to foreign capital in managing SDA. At the global level, this is also inseparable from the government's need for donor institutions in terms of disbursing aid funds to deal with crises, especially economic crisis, which at that time faced the Indonesian people who needed foreign assistance.

One of the conditions for borrowing in the government agreement and the International Monetary Fund (IMF) is the existence of structural adjustments. When the memorandum of understanding between the RI-IMF was signed, there were a number of requirements related to natural resources and the environment. Among them are directly related to conglomerates and trade arrangements. In addition, there are also world banks that provide a signal for loans that are directly related to forest management and other natural resources.

Structural adjustments are a systematic process and measurement of structural changes, in the form of national policy reforms that cover aspects of economic reform, decentralization reform, renewal of legislation, renewal of government organizations, capacity building at the local, regional and national levels. In Indonesia, this policy is contained in 50 items consisting of fiscal, monetary and banking, trade, investment and deregulation restructuring, BUMN privatization, and natural and environmental resources management. ${ }^{1}$

In the report of the results of a world bank study on SDA in Indonesia in 1997 concluded that Indonesia needed to immediately make changes in the approach, perspective and implementation of natural resource management. Some of these changes are from the provision of water for agriculture, the more equitable water allocation for other sectors. From focusing on the supply approach (supply approach) to demand management approaches and balanced supply approaches. Furthermore, it is also recommended that the world banks do not provide further assistance for the natural resources and irrigation sectors unless there is an effort to reform the sector.

The recommendation is contained in the SDA policy restructuring program better known as WATSAL

\footnotetext{
${ }^{1}$ See the explanation of Law Number 5 of 1960 concerning Basic Agrarian Principles.

Imam Soetiknjo.1990. National Agrarian Politics. Yogyakarta: Gadjah Mada University Press. Page. 37.
} 
(Water Resources Sector Adjustment Loan). This program is associated with structural adjustment loans that are quick disburse to overcome Indonesia's balance of payments due to the 1997 monetary crisis. ${ }^{1}$

Some of the problems that arise in Law Number 7 of 2004 concerning Water Resources relate to the involvement of the private sector in the management process. This is inseparable from the shift in the meaning of water which was previously a public good turned into a commodity that is more concerned with aspects of the economy which ultimately are oriented to profit seeking. This shift in meaning can be seen in the regulation concerning Water Use Rights that can be given to the private sector as seen in Article 9 paragraph (1), Article 11 paragraph (3) and Article 14 of Law Number 7 of 2004 concerning Water Resources. $^{2}$

The same applies to the implementing regulations, namely Government Regulation Number 16 of 2005 concerning Drinking Water Supply Systems (SPAM). Private space in water management is very large. This can be seen in Article 37 paragraph (3), namely "in the case of SOEs or BUMD as meant in paragraph (2) unable to increase the quantity and quality of SPAM services in their service areas, BUMN or BUMD with the approval of the supervisory board / commissioner may include cooperatives, private business entities and or communities in the implementation in their service area ".

In addition, Article 64 paragraph (1) of Government Regulation Number 16 Year 2005 concerning SPAM also states that private enterprises and cooperatives can participate in the implementation of the development of Drinking Water Supply Systems (SPAM) in regions, regions or regions that have not been reached by BUMN services / BUMD. Furthermore, in paragraph (3) of the same article it is also stated that the involvement of cooperatives and private business entities is carried out based on the principle of fair competition through the auction process.

The spirit of privatization with the involvement of the private sector in drinking water management in this PP as contained in Article 37 paragraph (3), Article 64 paragraph (1), paragraph (3) and paragraph (4) contradicts the provisions contained in Article 37 paragraph (1) PP Number 16 of 2005 concerning this SPAM. It was emphasized that "the development of SPAM is the responsibility of the government or regional government in ensuring the right of everyone to get drinking water for minimum daily basic needs in order to fulfill a healthy, clean and productive life in accordance with the laws and regulations". ${ }^{3}$

Several provisions in the PP above show that the government wants to free itself from responsibility for the provision of drinking water for its people by providing a broad space for the private sector in the management of drinking water. The trick is to build partnerships with the private sector and in the development of drinking water supply. This again will certainly change the meaning of water which previously public goods that fulfill it are the obligations of the government. The result is positioning water as an economic commodity where only certain people can access it.

This is of course contrary to the spirit of togetherness. That water as a natural asset that is very vital for the people to fulfill their needs has long been realized by the founders of this nation, so that the exploitation must be carried out by the state by providing access for all the people. Management is not submitted and carried out by the private sector without the state's role in it.

The Indonesian state constitution basically does not cover private participation in the implementation of production branches which control the livelihoods of many people, including the provision of drinking water. But the participation of the private sector must not eliminate the meaning of control by the State. Private participation can be carried out within the framework of cooperation and in the stages of implementation that do not hinder the state in the operation of drinking water. ${ }^{4}$

The limits mentioned above are not explained in Law Number 7 of 2004 concerning Water Resources, thus allowing room for water privatization. If this is the case, then this is very contrary to the mandate of the 1945 Constitution of the Republic of Indonesia, specifically Article 33 paragraph (2) of the 1945 Constitution of the Republic of Indonesia which affirms that the branches of production are important to the State and which control the livelihood of many people are controlled by the State. Therefore the involvement of the private sector is still possible as long as it is collaborative and responsible to the government. This is to continue to provide guarantees and improve the welfare of all people. ${ }^{5}$

Therefore, in a critical legal perspective, changes to Law Number 11 of 1974 concerning Water, indicate the pressures of globalization actors in legalizing privatization in Indonesia. In facing the pressure of these actors, it turns out that the government is powerless. As a result, rights to water in the context of human rights To respond to the capitalistic law of water resources, contrary to human rights and justice, intelligence and creativity are

\footnotetext{
${ }^{1}$ According to Muh. Yamin, people's welfare which is the basis and objective of the Independent Indonesia State is in summary public justice or social justice (Minutes of the BPUPKI Session, PPKI, RI State Secretariat, 1995, p. 28.

${ }^{2}$ Whereas social justice according to Soekarno is a society or a just society and prosperous, happy for everyone, no insult, no oppression, no exploitation. See: Soekarno. 2001. Keep the Pantjasila: Pancasila the Basic Philosophy of the State. Jakarta: Yayasan Kepangsaku. Page 170.

${ }^{3}$ Ibid. Page. 172

${ }^{4}$ Ibid.

${ }^{5}$ Natonegoro. 1974. Pancasila Basic State Philosophy. Jakarta: Prompt Tudjuh. Page. 37-38.
} 
needed, namely by abandoning the positivistic mindset and changing to a substantive mindset, as well as referring to the philosophy and values that favor the interests of the nation itself. ${ }^{1}$

Therefore it became increasingly clear that the birth of Law Number 7 of 2004 concerning Water Resources was strongly influenced by donor institutions as one of the global forces to pass the privatization process in Indonesia. This is inseparable from the amount of water that is getting increasingly limited the number of days which ultimately puts water as a very profitable commodity to be traded.

\section{The Right to Water as a Human Right}

Water which has the chemical formula $\mathrm{H} 2 \mathrm{o}$, is the essence of life. Water including substances cannot be replaced. The vitality of water for human life is the same as oxygen (O2). Without water, not only humans but all living things on this earth cannot survive. Therefore, the right to water is the most fundamental right for human life. At the commodity level, its existence is as human rights, even the most fundamental rights.

At the international level, various covenants at the United Nations even state that not only water itself is a right, but that access to clean water becomes Human Rights. But the fact shows that the fulfillment of the right to water for some of the world's population, including Indonesia, has not been achieved.

This fact encourages efforts to fulfill the right to water to be included as one of the Millennium Development Goals (MDGs) as the 10th target. The target is set to reduce half of the world's population who do not have access to clean water and sanitation in 2015. The achievement of these targets is important because the World Health Organization (WHO) in 2003 reported that of the 6 billion world population, there were still 1.1 billion people who do not have access to clean water and 63\% are in Asia, 28\% in Africa, 7\% in Latin America and the Caribbean, 2\% in Europe.

Compared to other types of water, essential clean water has been on the brink of crisis. The problem of clean water in general can be divided into three, namely: (1) the problem of quantity; (2) quality problems; and (3) distribution problems. Quantitatively, there is very little clean water that can be consumed by humans on earth. As much as $97 \%$ of the water on the earth's surface cannot be consumed by humans. Of the remaining $3 \%$, two thirds are trapped in ice in Antarctica or far away at the bottom of the earth. So the amount of water that can be consumed by humans is only around $1 \%$. This amount of $44,000 \mathrm{~km} 3$ is actually enough to meet basic needs per person, but the problem is that the availability is not evenly distributed throughout the world and some of the freshwater is of poor quality, or has been contaminated by waste.

In terms of world water distribution, the Latin American region has $31 \%$ of the world's water availability, so its population gets 12 times more water than those in South Asia, while other countries such as the Middle East, water availability is much smaller than what is needed the population. In general, in Indonesia, 2,799mm / year of rainfall has an abundant level of water availability, which is an average of $15,500 \mathrm{~m} 3$ per person per year ( 9 times the minimum requirement of $1,700 \mathrm{~m} 3$ per person per year).

Distribution problems arise as a major problem besides their availability which is very dependent on the season. Java Island which only has $4.5 \%$ of national freshwater potential but must support $65 \%$ of Indonesia's population, as a result Java Island often experiences a water crisis, especially in the dry season. As a result of global climate change, climate patterns also change significantly.

Since the 1990, data has shown that drought comes earlier around 3 months and retreats around 2-4 months. This means that the duration of the dry season has increased by more than two months. This is what makes the magnitude, area, and intensity of floods and droughts increasingly terrible. The state of the season in a country will affect the seasons of other countries, so the water problem that is strongly associated with the season is no longer a local and national issue, but has become a global issue (global issue).

In the context of legal politics, the legal politics used as the basis for the development of the national economy are the values of social justice that are embodied in the main principles. That is, the production branches that are important to the state and control the livelihoods of many people are controlled by the state, secondly, the earth and water and the wealth contained in them is controlled by the state and used for the greatest prosperity of the people.

In the clarification of Article 33 it is expressly stated that companies that are important to the state and control the livelihood of many people must be in the hands of the state because if they are in the hands of individuals, the people will be oppressed. So based on this spirit, it can be stated that the privatization of the management of natural resources clearly contradicts the spirit of Article 33 of the 1945 Constitution of the Republic of Indonesia Pre-amendment.

\footnotetext{
1 In the economic field capitalism defines the elements by which material elements and factors of production (land and capital) are in the hands of the private sector and the most important motivation in production is solely to seek as much profit as possible. (Encyclopedia of Indonesia. Jakarta: Van Hoeve. Page. 1659). In terms of process, capitalism is an economic system that only recognizes one law: the law of bargaining in the market. So capitalism is a free economy, free from various restrictions from the ruler and the king (people may sell goods in any market), free from labor restrictions, which determines solely only profits to be obtained. See: Franz Magins Suseno.2000. The thinking of Karl Marx: From Utopian Socialism to the Disputes of Revisionism. Jakarta: General Library Gramedia. Page. 163-164.
} 
The politics of economic law can thus be referred to as the legal politics of Indonesian socialism. However, the practice in the field of Indonesian economy has entered the libral phase of capitalism since the promulgation of Law No. 1 of 1967 concerning Foreign Investment. In this case it can be predicted that the sovereignty of the state over natural resources, especially on water, is threatened and even eroded.

If it is not maintained, then it has the potential to violate human rights. This was confirmed by the United Nations in its session in 2002. In its general session, the UN affirmed the agreement that water is a human right. Article I.1 of the UN Decree states that: "The human right to be indispensable for leading life in human dignity. It is prerequisite for the realization of other human rights." That is, each country is responsible for providing clean water, for drinking and for sanitation for all their citizens. Without water, other human rights cannot be exercised.

\section{Legal Politics of Resources in the Era of Globalization}

The wave of globalization, like it or not, likes or dislikes experienced by all residents in all countries in the world. Indonesia cannot avoid the impact. In the constitutional field of the Republic of Indonesia, the constitution is required to adjust the global development. As a result, the 1945 NKRI Constitution Amendment was carried out. The comparison between Article 33 of the 1945 Constitution of the Republic of Indonesia in pre-amendment and post-amendment is as follows:

In Article 33 of the Pre-amended 1945 Constitution it is stated that the Economy is structured as a joint venture based on the principle of family. For production branches that are important to the state and control the livelihood of many people controlled by the state. Whereas the earth and water and the wealth contained therein are controlled by the state and are used for the greatest prosperity of the people. ${ }^{1}$

In Article 33 of the 1945 Constitution of the Republic of Indonesia Republic of Indonesia after amendments or amendments, it was stated that:

1. The economy is structured as a joint effort on the principle of family.

2. Production branches that are important to the state and control the livelihood of many people are controlled by the state.

3. Earth and water and the wealth contained therein is controlled by the state and used for the greatest prosperity of the people.

4. The national economy is organized based on economic democracy with the principle of togetherness, efficiency in justice, sustainability, environmental insight, independence and by maintaining a balance of progress and unity of the national economy.

5. Further provisions regarding the implementation of this article are regulated in law. ${ }^{2}$

Before Article 33 of the 1945 Constitution of the Republic of Indonesia was amended, the Indonesian economic system should be developed by fulfilling several principles in paragraphs (1) (2) and (3) as a framework. Based on these verses the legal politics of Indonesia's national economy would be directed at an economic construction called Indonesian Socialism.

Such legal politics clearly rejects the control of the earth, water and natural resources contained therein by individuals or the private sector as stated in the General Amendment to the 1945 NKRI Constitution amended, there are additions namely paragraph (4) and paragraph (5), while paragraph (1), verse ( 2) and paragraph (3) remain the same.

In paragraph (4) it is basically a means to adopt the principles of the modern economy with various global economic indicators that are actually capitalistic liberal spirits, for example the principles of efficiency (profit, anti-subsidy), justice (individual), and independence (individual responsibility). So through the addition of paragraph (4), the legal politics of Indonesia's national economy has undergone a shift from Indonesian Socialism to Neo-Indonesian Socialism based on the concept of good corporate governance that has characteristics of accountability, transparency and democracy.

The Indonesian economy is faced with a wave of globalization that has a tendency to adhere to the flow of capitalistic liberalism or the global capitalist system that demands the existence of privatization on almost all lines of economic life in a country. The assumption that arises is that the privatization is carried out so that foreign companies, foreign investors, can enter as investors or shares while at the same time instill their

\footnotetext{
${ }^{1}$ Jimly Asshidiqie. 2006. Independence of Association, Dissolution of Political Parties, and Constitutional Court. Jakarta: Secretariat General and Registrar's Office of the Court. Page. 43.

${ }^{2} \mathrm{http} / / /$ www.cnnindonesia.com/ekonomi/20160119102118-78-105232/utang-luar-negeri-indonesia-tembus-rp4234-triliun/. declared by Bank Indonesia (BI) recorded Indonesia's Foreign Debt up to November 2015 through the US \$ 304.6 billion figure or around Rp.4,234 trillion. If compared on an annual basis or year on year (YoY), Indonesia's Foreign Debt position per November 2015 grew 3.2 percent or higher compared to its growth in October 2015 which only reached 2.5 percent. For short-term external debt, the amount is recorded to be depreciated by 12.5 on an annual basis. Meanwhile, if based on the original period, Indonesia's external debt position is still dominated by long-term external debt of 86.6 percent, or around US \$ 263.0 billion consisting of sector external debt public as much as US \$ 134.8 billion and private sector external debt reached US \$ 129.1 billion.
} 
influence on the scale of the national economy. Indonesia, including in Asia, has a large amount of foreign debt. ${ }^{1}$

The debt comes from donor countries that are members of the International Monetary Fund (IMF) and Consultative Group on Indonesia (CGI) or the World Bank. Loans provided by the IMF, CGI and the World Bank have special requirements which include privatization in several economic fields, one of which is investment in natural resources. This effort was taken by the Indonesian government by issuing Law No. 7 of 2004 concerning Water Resources, which is then abbreviated as UUSDA.

At first the idea of being published by UUSDA in 2004 was based on the reason that Law No. 11 of 1974 concerning Irrigation is deemed not in accordance with the demands of the development of the situation, and the factor of changes in people's lives is also a reason so it needs to be replaced with a new law. UUSDA is based on several considerations:

a. SDA is the gift of God Almighty who benefits all fields;

b. The imbalance between the availability of water which tends to decrease and the increasing need for water, natural resources must be managed by paying attention to social, environmental and economic functions in harmony;

c. Management of natural resources needs to be directed at realizing a synergy of harmonious integration between regions, between sectors, and between generations;

d. In line with the spirit of democratization, decentralization, and openness in the order of life in the community, nation and state, the community needs to be given a role in the management of natural resources. $^{2}$

In terms of state sovereignty over water, this UUSDA limits the role of the state merely as a regulator and regulator. The state is limited to being a regulator and the private sector as the organizer of the water system is a description of the application of a liberal economic system. The state is limited to regulators who will lose control over each stage of water management to ensure the safety and quality of service for every water user. The state cannot guarantee and provide protection to disadvantaged and vulnerable groups in obtaining access to adequate, healthy and affordable water,

The social role cannot be replaced by the profit-oriented private sector as the main objective. UUSDA also provides a broad space for the private sector to master water sources (ground water, all forms of surface water, and some river bodies). The Instrument of Use Rights in Article 7, Article 8, Article 9, and Article 10 forms the basis for the allocation and control of water resources to private usasha individuals and bodies or the entry into the privatization of natural resource management.

If efforts to privatize and commercialize water continue to be carried out even though UUSDA has been canceled, it means that the Indonesian nation can be considered not to have a sense of crisis against water conflicts. In 2004 the International Food Policy Research Institute (IFPRI) indicated that the water problem had entered a serious stage, therefore priority was needed to deal with it. IFPRI predicts that the next 25-30 years the need for drinking water will rise by around $285 \mathrm{~km} 3$, for agricultural irrigation it will increase by $655 \mathrm{~km} 3$, and for others (industry) it will increase by $230 \mathrm{~km} 3$. In the World Water Forum in Kyoto Japan, March 2003, it was explained that 1 out of 5 developing countries will experience water shortages in 2030, even though in that year it was estimated that water demand for agriculture would increase by $14 \%$, together with an increase in $60 \%$ of food needs.

Indonesia has bad experience about privatization of production branches which are important for the state and affect the livelihoods of many people. The privatization of several economic sectors has been carried out by the government, including the privatization of several State-Owned Enterprises (BUMN) in the field of electricity, cement and telecommunications. At the praxis level, the process of building domestic market institutions within the framework of the privatization policy framework does not work as it should, as a result of the sterility of implementing economic regulation. Various short-term practical interests always defeat the importance of building stable market institutions.

The phenomenon of the privatization of PT Indosat and the privatization of PT Semen Gresik for example, can be used as a reference case that reflects the government's failure to build domestic market institutions in implementing privatization policies. In both of these phenomena there have been at least two basic violations of the privatization regulation, namely: The Privatization Committee does not use the standard criteria listed in Law No. 19 of 2003 concerning State-Owned Enterprises that also regulate the issue of privatization.

Next, regulation deviations and entanglements in short-term practical interests, in the process of determining share prices of PT Indosat and PT Semen Gresik. Decision making on the privatization of PT Indosat and PT Semen Gresik is very detrimental to the Indonesian state. This is a very valuable lesson not to repeat itself, what else is on a product that is very strategic like this water.

\footnotetext{
${ }^{1}$ Andri G. Wibisana, Three Principles of Environmental Law: The Polluter-Pays Principle, The Principle of Prevention, and the Precautionary Principle, in Michael Faure \& Nicole, Niessen (edited), Environmental Law in Development, Lesson from the Indonesian Experiment, Cheltenham UK-Northampton, MA, USA: Edward Elgar Publishing, Inc., 2006,. Page. 41.

${ }^{2}$ Sedarmayanti, Good Governance in the Framework of Regional Autonomy. Bandung, Mandar Maju, 2003. Page. 4
} 


\section{Law Enforcement of Water Pollution Actors.}

The term water pollution or water pollution can be perceived differently by one person with another person considering that many reference libraries formulate the definition of the term, either in a dictionary or scientific text book. The definition of water pollution is also defined in Government Regulations, as derived from the definition of environmental pollution defined in the law. In its operational practices, environmental pollution has never been fully demonstrated, but rather as pollution from environmental components, such as water pollution, seawater pollution, groundwater pollution and air pollution. Thus, the definition of water pollution refers to the definition of the environment stipulated in the Law on the environment, namely Law No. 23/1997.

In PP No. 20 of 1990 concerning Water Pollution Control, water pollution is defined as: "water pollution is the entry or inclusion of living things, substances, energy and / or other components into water by human activities so that the quality of water drops to a certain level which causes water to no longer function in accordance with the designation "(Article 1, number 2). The definition of water pollution can be described according to its main meaning into 3 (three) aspects, namely aspects of events, aspects of causes or actors and aspects of consequences.

Based on the definition of water pollution, the cause of pollution can be in the form of the entry of living things, substances, energy or other components into the water, causing the quality of contaminated water. This input is often referred to as the pollutant element, which in practice is in the form of routine discharge, such as liquid waste disposal. Aspects of actors / causes can be caused by nature, or by humans. Pollution caused by nature cannot have legal implications, but the Government still has to overcome the pollution. While the impact aspect can be seen based on a decrease in water quality to a certain level.

The definition of a certain level in the definition is the level of water quality which is the boundary between the level of pollution (the level of water quality has not reached the limit) and the level of pollution (water quality that has reached the limit or crossed the limit). There are certain quality standards for water designation. An example is the Health Act No. 23 of 1992 paragraph 3 implies that drinking water consumed by the public must meet the requirements of quality and quantity, the quality requirements contained in the Regulation of the Minister of Health No. 146 of 1990 concerning conditions and supervision of water quality. While the parameters of the quality of drinking water / clean water consisting of chemical, physical, radioactive and microbiological parameters, are stipulated in PERMENKES 416/1990.

Safe water is water that matches the criteria for the water allotment. For example the criteria for water that can be drunk directly (water quality A) has different criteria than water that can be used for drinking water (quality B) or quality $\mathrm{C}$ water for fisheries and livestock purposes and quality D water for agricultural and urban business purposes, industry and hydropower plants. Examples of water criteria A, B, C and D can be seen in the Appendix.

Law enforcement is called in English law enforcement, rechshanhaving Dutch. The term law enforcement in the Indonesian language leads us to the idea that law enforcement is always with force so that some argue, that law enforcement is only concerned with criminal law. This kind of thinking is reinforced by our habit of calling law enforcers police, prosecutors and judges. It is not called an administrative official who is actually a law enforcer. The term foreign words are copied into "law enforcement", more in accordance with the context of this law. broader scope.

Handhaving according to Notitie Milieurech Handhaving, 1981 is the supervision and application (or with threats) of the use of administrative, judicial or civilian instruments achieved by the determination of general and individual legal and regulatory provisions. Control means government supervision to comply with regulations that are parallel to investigations in criminal law.

In addition, or before law enforcement is held, negotiations, persuasion, and supervision are often held so that legal regulations or permit conditions are adhered to. This can be called compliance.

Environmental law is very complicated, many of its contents, violations are also diverse, ranging from the lightest ones such as the disposal of kitchen waste to the most dangerous ones such as the disposal of hazardous and toxic waste and atomic radiation.

Therefore the response is also diverse, ranging from legal information to the application of sanctions. An application of environmental law needs to be encouraged from mass media such as newspapers, radio, television, to lectures and discussions. Thus, violations can be prevented as early and as widely as possible. Addressing environmental problems must start from oneself to the wider community.

Enforcement of environmental law as mentioned before is very complicated, because environmental law occupies a cross point in various fields of classical law. It can be applied with one instrument, namely an administrative, civil or perhaps criminal law can be enforced with three instruments at once.

Therefore, enforcers of environmental law must also master various fields of classical law such as government law (administrative), civil law and criminal law, even to tax law, land, state administration, international (public and private).

The purpose of environmental protection and management according to article 3 of UUPPLH-2009 is: 
a. protect the territory of the Unitary State of the Republic of Indonesia from pollution and / or environmental damage;

b. guaranteeing safety, health and human life;

c. guarantee the continuity of life of living beings and ecosystem preservation;

d. maintain the preservation of environmental functions;

e. achieve harmony, harmony; and environmental balance;

f. guaranteeing the fulfillment of the justice of present and future generations;

g. guarantee the fulfillment and protection of the rights to the environment as part of human rights;

h. controlling the use of natural resources wisely;

i. realize sustainable development; and anticipate global environmental issues.

To achieve this goal, then in UUPPLH-2009 this was carried out to strengthen the principles or legal principles both related to the substance of environmental law and procedural aspects to enforce the substance of the law. The legal principle or principle that is used as the basis for legal arrangements for environmental protection and management mentioned explicitly in article 2 of UUPPLH-2009 is:

a. Principle of State Responsibility.

The principle of state responsibility is explained in the explanation of article 2 letter a UUPPLH-2009. This principle means that:

- the state guarantees that the use of natural resources will provide the maximum benefit for the welfare and quality of life of the people, both present and future generations;

- the state guarantees the rights of citizens to a good and healthy environment;

- the state prevents the use of natural resources activities that cause pollution and / damage to the environment.

b. Principles of Sustainability and Sustainability (Preservation and Sustainability Principle).

The principle of sustainability and sustainability is explained in Article 2 letter b UUPPLH-2009. According to the explanation of this article referred to as the principle of sustainability and sustainability that: "every person bears the obligations and responsibilities of future generations and of his fellow human beings in one generation by making efforts to preserve the carrying capacity of the ecosystem and improve the quality of the environment". This explanation is actually inappropriate, because what is explained is the principle of intergenerationalequity and one generation justice (Intragenerational equity). As stated in the third principle of the Rio Declaration which reads: "The right to development must be fulfilled so as to equitably meet developmental and environmental needs of present and future generations".

In the context of development, the principle of sustainability requires choosing alternative development that saves resources and is able to harmonize conservation aspects with aspects of utilization wisely. The sustainability principle also requires the use of energy-efficient development and consumption patterns, saving raw materials, and saving natural resources.

\section{c. Harmony and Balances Principle.}

This principle is a principle derived from the principle of sustainable development that combines economic, socio-cultural, and environmental aspects in development. As explained in Article 2 letter c UUPPLH-2009 that what is meant by the principle of harmony and balance is that "the use of the environment must pay attention to various aspects such as economic, social, cultural, and protection and preservation of ecosystems". Thus, environmental aspects must be an integral part of the development process.

\section{d. The Principle of Integratedness.}

The principle of integration according to the explanation of Article 2 letter $\mathrm{d}$ of UUPPLH-2009 states that "protection and management of the environment is carried out by combining various related components". This principle is implemented in the integration of three new legal instruments in UUPPLH-2009 namely the Environmental Protection and Management Plan (RPPLH), Strategic Environmental Assessment (SEA), and environmental permits. In the context of law enforcement, the principle of integration is also reflected in the integrated law enforcement of environmental crimes between investigators of civil servants (PPNS), police, and prosecutors under the coordination of the Minister (Article 95 paragraph 1 UUPPLH-2009). Such integration includes the integration of elements environment, integration in management, and integration of stakeholders.

e. Benefit Principle.

The principle of benefit according to the explanation of Article 2 letter e that "all business and / or development activities carried out are adjusted to the potential of natural resources and the environment to improve people's welfare and human dignity in harmony with their environment". The explanation of the article implies that environmental management must provide good benefits ecologically and economically and socially. These three benefits are the core goals of sustainable development. Thus, the principle of benefit cannot be separated from the principle of sustainability and sustainability and harmony and balance.

f. Precautionary Principle.

The precautionary principle is related to early prevention of high-risk activities. According to the explanation of 
Article 2 letter $\mathrm{f}$ of UUPPLH-2009 referred to as the precautionary principle that "uncertainty about the impact of a business and / or activity due to limited mastery of science and technology is not is an excuse to delay the steps to minimize or avoid threats to environmental pollution and / or damage. "The provisions concerning the analysis of environmental risk as stipulated in article 14 letter k and Article 47 of the Company Law 2009 are in line with the precautionary principle, which was previously not regulated in UUPLH-1997.

\section{g. Principle of Justice (Equitable Principle).}

The principle of justice according to the explanation of Article 2 letter g UUPPLH-2009 that "protection and management of the environment must reflect proportional justice for every citizen, both across regions, across generations, and across gender". Justice in question is justice in terms of obtaining equal treatment in terms of access to natural resources, proportional distribution of benefits and burdens, equal opportunities in obtaining benefits from economic resources, and in bearing losses due to the development process.

\section{h. Ecoregion Principle.}

The principle of ecoregion is the principle of environmental management that has just been confirmed in UUPPLH-2009. According to the explanation of article 2 letter $h$ UUPPLH-2009, what is meant by the ecoregion principle that "protection and management of the environment must pay attention to the characteristics of SDA, ecosystems, geographical conditions, culture of local communities, and local wisdom ". From this explanation it is clear that environmental management cannot be strictly limited by the administrative-regional approach. Ha this is because the environment has ecological characteristics that have administrative boundaries (beyond the administrative boundary).

\section{i. Principle of Biodiversity Principle}

According to the explanation of article 2 letter i UUPPLH-2009, what is meant by the principle of biodiversity that "protection and management of the environment must pay attention to integrated efforts to maintain the existence, diversity and sustainability of biological natural resources consisting of vegetable natural resources and animal natural resources together with non living around it as a whole forms an ecosystem.

This principle is very important because today's biodiversity has experienced a marked reduction and loss, so it is feared that it will disrupt the balance of the living system in the earth and in turn will disrupt the sustainability of human life.

\section{j. Principle of Paying Pollutants (Polluter Pays Principle)}

The main objective of this principle is to internalize environmental costs. In UUPPLH-2009 the principle of polluter pay is contained in article 2, which is then elaborated in article 14 letter h, article 42 and 43 . Such principle arrangements include provisions regarding the introduction of environmental costs, funds guaranteeing environmental recovery, environmental taxes and retributions.

\section{k. Participation Principle}

In Article 2 letter $\mathrm{k}$ UUPPLH-2009, it is explained what is meant by the participatory principle that "every member of the community is encouraged to play an active role in the decision-making process and the implementation of protection and environmental management, both directly and indirectly". This principle is one of the important principles other than as an effort to empower the community in implementing environmental management, as well as to improve the quality of decisions and community acceptance of government decisions related to the environment.

\section{l. Local Wisdom Principle}

This principle implies that environmental management must pay attention to the values, customs or customary laws that apply to the local community. This is explicitly acknowledged and explained in article 2 letter 1 UUPPLH-2009 that "in the protection and management of the environment must pay attention to the noble values that apply in the order of life of the community".

\section{m. Principle of Good Governance (Good Governance Principle).}

The concept of good governance is one of the central issues which lately has become a discourse in the administration of government. In essence, the concept of good governance requires the implementation of effective and efficient governance. This demand is intensely carried out by the community in line with the increasing level of public knowledge and education., and the influence of globalization. In relation to environmental management, the principle of good governance according to the explanation of article 2 letter $\mathrm{m}$ UUPPLH-2009 states that "environmental protection and management are inspired by the principles of participation, transparency, accountability and justice".

\section{n. Principle of Regional Autonomy.}

According to the explanation of article 2 letter n UUPPLH-2009 that "the government and regional government regulate and manage their own government affairs in the field of environmental protection and management by taking into account the specificity and diversity of regions within the frame of the Unitary State of the Republic of Indonesia". 


\section{Environmental Law Enforcement Process on Water Resources}

Water pollution control / mitigation in Indonesia has been regulated through Government Regulation No. 82 of 2001 concerning Management of Water Pollution Quality and Control. In general, this includes water pollution by agencies or non-agencies. One of the serious efforts that the Government has made in controlling water pollution is through the Clean River Program (PROKASIH).

This program is an effort to reduce the burden of liquid waste, especially those originating from medium and large scale business activities, as well as being carried out in stages to control the pollution load from other sources. The program also seeks to organize settlements on the banks of the river by involving local communities.

In principle, there are 2 (two) businesses to overcome pollution, namely mitigation in a non-technical and technical manner. Non-technical mitigation is an effort to reduce environmental pollution by creating legislation that can plan, regulate and supervise all forms of industrial activities and technology so that pollution does not occur. These laws and regulations should be able to provide a clear picture of the industrial activities to be carried out, for example, covering AMDAL, regulating and monitoring activities and instilling disciplinary behavior. While countermeasures are technically sourced from industrial treatment of the treatment of waste, for example by changing processes, managing waste or adding assistive devices that can reduce pollution.

Actually, prevention of water pollution can start from ourselves. In everyday life, we can reduce water pollution by reducing the minimization of production that we produce every day. In addition, we can also recycle and recycle the waste. We also need to pay attention to the chemicals we dispose of in our homes. Because now we have become a chemical society, which uses hundreds of types of chemicals in our daily lives, such as washing, cooking, cleaning houses, fertilizing plants, and so on. We must be responsible for various wastes such as canned food, bottled drinks and so on, which contain coloring elements on the packaging and then absorbed by ground water at the final disposal site. Even our choice to drive or walk, contributes to the emission of acids or hydrocarbons into the atmosphere which ultimately impacts on the natural water cycle.

Being a responsible consumer is wise. For example, is it critical of the goods consumed, will it later become a source of disasters that are persistent, explosive, corrosive and toxic or degradable? Will the goods we consume later poison humans, animals and plants safely for living things and the environment?

We can use technology to overcome water pollution. Clean water treatment plants, wastewater treatment plants, which are operated and maintained properly, are capable of removing toxic substances from polluted water. In terms of policies or regulations, this water pollution already exists. If we really want it to be implemented, then law enforcement must also be implemented. In the end, there are many choices both personally and socially (collectively) that must be determined, consciously or not, which will affect the level of pollution wherever we are. However, prevention measures are more effective and prudent.

In general the problem starts at one point, namely the occurrence of violations of environmental law. From this departure point can be started from private members of the community, law enforcement victims who know firsthand the occurrence of violations without a report or complaint. The purpose of reporting to Bapedal Office of Environment also varies. because early can find out whether there is true pollution or environmental damage. They have a special laboratory, and from laboratory inspection it can be seen the occurrence of violations (exceeding the threshold).

From the LH Office, the next process can be chosen. If still in doubt, about which provisions are violated, are the administrative provisions (violation of licensing), whether they are civil (for example, violating the law) or do they need to proceed to criminal law processes for example if the violator is a recidivist. The LH office should bring the matter to the discussion forum as mentioned earlier. However, if the recipient of the report considers that this violation can still be repaired or restored by administrative force (bestuursdwang), then it can be forwarded to the issuing permit (for example the local government) to be addressed immediately if there is sufficient compliance (negotiation, information, advice, and so on), or crackdown, for example withdrawal of permits (for example in the case of an hinder ordinnantie).

The following will be explained about the means of law enforcement:

\section{a. Administrative.}

Administrative means can be preventive and aim to enforce environmental legislation (for example: Law, PP, Ministry of Industry Decree, Mayor's Decree, etc.). Law enforcement can be applied to activities involving licensing requirements, environmental quality standards, environmental management plans (RKL), and so on. Besides the guidance in the form of instructions and guidance as well as administrative supervision, entrepreneurs in the industrial sector should also inculcate the benefits of the concept of "Pollution Prevention Pays" in the production process.

Administrative facilities can be enforced by the ease of environmental management, especially in the financial sector, such as relief of import duties for prevention of pollution and bank credit for environmental management costs and so on. Repressive repression by the authorities against violations of the laws and 
regulations of the administrative environment basically aims to end the prohibited condition directly. ${ }^{1}$

Administrative sanctions mainly have instrumental functions, namely control of prohibited acts. In addition, administrative sanctions are primarily aimed at protecting the interests guarded by the violated provisions. Some types of administrative law enforcement are:

a.1. Government coercion or forced action (Bestuursdwang);

With regard to the coercion of this government, F.A.M Stroink and J.G. Steenbeek said that the most important authority that can be exercised by the government to enforce material administrative law is the coercion of the government. The authority of coercive governance can be described as the authority of government organs to take concrete actions to end situations that are contrary to the legal norms of state administration because the obligations arising from the norm are not implemented or as a reaction from the government for violations of legal norms carried out by citizens. Government coercion is seen as a form of real execution, in the sense that it is immediately carried out without the mediation of the judges (parate executie), and the costs associated with implementing this coercive government can be directly imposed on the offender. The authority of the government to use estuurdswang is free authority in the sense that the government is given the freedom to consider its own initiatives whether or not to use bestuurdswang or even apply other sanctions.

a.2. Forced money (Publiekrechtelijke dwangsom);

The imposition of forced money can be imposed on a person or citizen who does not comply or violates the provisions stipulated by the government as an alternative or coercive government. The purpose of the decision to impose forced money is to eliminate or terminate the violation. forced money. The imposition of forced money is an alternative to real action which means as a sanction (subsidiaire) and is considered a sanction for reparations. The legal problems faced in the imposition of forced money are the same as the implementation of real coercion.

a.3. Closure of place of business (Sluiting van een iNKRIchting)

Provisions regarding the closure of business premises as stipulated in the articles above do not explicitly call it, but according to the doctrine of one administrative sanction is the closing of the office as stated by Siti Sundari that one administrative sanction is the closure of the company. In addition, also, before the government imposed even more stringent sanctions, namely the revocation of business licenses, it is usually carried out especially the closing of business premises as a strong warning against perpetrators of environmental violations. Actually the provisions concerning the closure of business premises relating to environmental disturbances have long been regulated in the Disruption Ordinance (Hinder Ordonanntie), in Article 14 it is stipulated about administrative sanctions in the form of closure of business premises by sealing machines, tools and auxiliary equipment used for that.

a.4. Revocation of Business License.

Violations of environmental regulations can be sanctioned by revoking business and / or activity licenses. As for the weight of violations of environmental regulations, they can vary from violations of administrative requirements to violations that cause victims of the community. Therefore, revocation of business and / or activities can be carried out against violations which are deemed to have a certain weight to be stopped from business activities. Revocation of business licenses is carried out by authorized officials or officials who give business licenses. Head of Region can propose revoking business licenses to officials those who are authorized for that, in addition to that, the parties concerned may submit an application to the competent authority to revoke the business license because it harms its interests. Thus, the authorized official can revoke the business license and / or activity at the proposal of the Head of the region concerned or at the request of interested parties.

b. Criminal law.

Satjipto Raharjo stated that the law protects a person's interests by placing a measure of power (certain and in it) to act in the context of that interest. The same is true of Salmond's opinion, which states that legal protection aims to integrate and coordinate various interests in the community because in the interest of the interests of protecting certain interests can only be done by limiting interests on the other hand. The legal interest is to take care of human rights and interests so that the law has the highest authority to determine human interests that need to be regulated and protected.

Philipus M. Hadjon defines legal protection as protection of dignity and recognition of human rights owned by legal subjects based on legal provisions of arbitrariness.10 In formulating the principles of legal protection in Indonesia, the foundation is Pancasila as an ideology and state philosophy. The concept of legal protection for the people in the West is based on Rechtstaat concepts and rule of the law. By using the western conception as a frame of mind with a foundation on Pancasila, the principle of legal protection in Indonesia is the principle of recognition and protection of human dignity and sources that originate from the Pancasila.

In essence the state has clearly regulated the protection given to its citizens in legislation, including the rights of the people other than Indonesian citizens. Regarding legal protection and guaranteeing the right to access the community to get clean water, the reference is to legislation in Indonesia. The legislation in question

\footnotetext{
${ }^{1}$ Siti Sundari Rangkuti, Environmental Law and National Environmental Policy, Airlngga University Press, Surabaya, 1996. Page. 192.
} 
is Law Number 36 of 2009 concerning Health, Law Number 32 of 2009 concerning Environmental Protection and Management, Government Regulation Number 82 of 2001 concerning Management of Water Quality and Water Pollution Control, and Regulation of the State Minister of Environment Life Number 1 of 2010 concerning Water Pollution Control Procedures.

Whereas in Law Number 36 of 2009, although it clearly regulates environmental health in regulating the quality of clean and healthy water, none of the articles regulates the resolution of legal protection issues and guarantees the right to good clean water in litigation (legal channels / court) and non-litigation (outside the court). This law regulates the right of a person to get a healthy environment for clean water, for achieving health status, but related to legal sanctions in Article 190 to Article 201, does not regulate legal sanctions for someone who seizes the rights of others to obtain water quality clean and healthy for the achievement of human health.

On this basis, the legal protection of the quality of clean water can be seen in Law No. 32 of 2009 concerning Protection and Management of the Environment, because this law regulates the mechanism for resolving water pollution disputes and granting sanctions (administrative sanctions and criminal sanctions) for perpetrators water pollution in Indonesia.

Judging from the provisions of Law No. 32 of 2009, criminal acts in the context of water pollution in Indonesia are regulated in Article 98 to Article 101 and Article 104. So that the perpetrators of criminal acts of water pollution can be subject to criminal sanctions based on these legal provisions.

\section{c. Civil law.}

Regarding this matter, it is necessary to distinguish between the application of civil law by an agency authorized to implement environmental policies and the application of civil law to carry out compliance with environmental legislation.

Civil Law Enforcement is an effort to restore the rights of parties who are harmed or restore environmental conditions due to pollution and / or environmental damage. The form of responsibility in question can be in the form of:

a. Compensation / Compensation; or

b. Certain actions to restore environmental conditions.

Responsibility in Civil Law can arise from both administrative and criminal offenses, as long as the violation causes harm to a party.

Responsibility can arise on the basis of a lawsuit by:

1. individual;

2. representative (class action);

3. government;

4. non-governmental organizations; or

5 . in the name of the citizen (citizen lawsuit).

By basing it on Liability based on Fault and Absolute Liability (Liability without Fault) (Vide: Decision of the Chief of the Supreme Court No. 36 / KMA / SK / II / 2013 concerning Application of Guidelines for Handling Environmental Cases ( "KMA 36/13")) which reads: "a serious threat is the occurrence of pollution and / or damage to the environment whose impacts have the potential to be irreversible and / or the components of the environment affected are very broad, such as human health, surface water, underground water, air, plants and animals. "

In addition, there is the possibility of "short-term action" (kortgeding) for interested third parties to sue compliance with laws and requests for prohibition or necessity to be linked to forced money (injunction).

If all paths will be taken because the violation has been so serious and alluding to dimensions, for example, violating the terms of a permit raises financial losses to people or the community. In order for the sanctions imposed do not overlap, for example, fines (based on administrative and criminal sanctions), law enforcers need to consult so that the actions taken by each are well coordinated. Finally, it should be noted that all the paths that can be taken require expert witnesses, who should be taken from or by the intermediaries of the office of the environment minister, among others, because they have special environmental laboratories.

\section{Cover}

From the results of the research and analysis conducted, it can be concluded as follows:

a. For Indonesia as an archipelagic country whose seas cover two-thirds of its national territory, and has the second longest coastline in the world, and also known as a maritime country, has a huge responsibility to protect its waters from water pollution. For this reason, the regulation of existing environmental law must be integrated and comprehensive. In addition, it is also necessary to apply the principles of cross-national pollution law in legislation that are regulated integratively.

b. However, the rule is only a rule if it is not accompanied by law enforcement. Law Enforcement in dealing with perpetrators of water pollution has a very important role, to cause deterrent effects (ultimumremedium). This needs to be done to bring about the authority of the law, which is expected 
to bring fundamental changes in people's attitudes to participate in every movement of national development. This meaning was offered by Mochtar Kusumaatmadja who adopted Roscoe Pound's thinking about "law as a tool of socialengering", namely law as a means of engineering society, which encouraged the creation of legislation and jurisprudence.

Regarding the results of the research and discussion that found deficiencies in the drafting of the Criminal Code Concept, the authors suggested that the proper sanction for perpetrators of water pollution is civil sanctions in the form of compensation which could later be used as a tool to rehabilitate the environment to return to normal. Because the people who experience the greatest impact in water pollution are the people in the surrounding environment, so that if the environment is not restored, the community will suffer and the "perpetrators" (companies and so on) will not experience the impact.***

\section{BIBLIOGRAPHY}

\section{Book}

Andri G. Wibisana, Three Principles of Environmental Law: The Polluter-Pays Principle, The Principle of Prevention, and the Precautionary Principle, dalam Michael Faure \& Nicole, Niessen (edited), Environmental Law in Development, Lesson from the Indonesian Experince, Cheltenham UK-Northampton, MA, USA: Edward Elgar Publishing, Inc, 2006.

Andi Hamzah, Penegakan Hukum Lingkungan,Sinar Grafika, Jakarta, 2008.

Arief Hidayat dan FX. Adji Samekto, Kajian Kritis Penegakan Hukum Lingkungan di Era Otonomi Daerah, BP. Undip, Semarang, 2007.

A. Sonny Keraf, Etika Lingkungan, Buku Kompas, Jakarta, 2002.

Danusaputo, Hukum Lingkungan Buku I, Bina cipta Jakarta, 1985

Endterwada, et.all, A Framework For Understanding Social Science Contribution To Ecosystem Pengurusant, Ecologycal Application, 891-904. Lihat juga dalam Djanius Djamin, Pengawasan dan Pelaksanaan UndangUndang Lingkungan Hidup: Suatu Analisis Sosial, Yayasan Obor Indonesia, Jakarta, 2007.

Effendi, Hefni, 2003, Telaah Kualitas Air Bagi Pengelolaan Sumber Daya danLingkungan Perairan, Penerbit Kanisius, Yogyakarta.

Fatimah, Isna. "Kinerja Pemerintah Daerah dalam Pengendalian Pencemaran Air,Pengawasan dan Penegakan Hukum Administrasi terhadap Industri yangBerpotensi Mencemari Sungai Brantas: Studi pada Badan Lingkungan HidupProvinsi Jawa Timur, Kab. Gresik, dan Kab. Mojokerto.”

Henry Campbell Black, Black's Law Dictionary 8th, US Gov, 2004.

Hein, Toward Improved Enviromental and Social Pengurusant of Indian Shrimp Farming, Enviromental Pengurusant.

J.M.D Jahi, Impak Pembangunan Terhadap ALam Sekitar, Oenerbit Universitas Kebangsaan Malaysia Bangi, 1996.

Kirsch, Enviromental Disaster: Culture Loss and The Law, Current Antropology, 2001.

Mahrus Ali, Dasar-Dasar Hukum Pidana, Sinar Grafika, Jakarta, 2011.

Masrudi, Muchtar., Abdul, Khair., Noraida, HUKUM KESEHATAN LINGKUNGAN (Kajian Teoritis dan Perkembangan Pemikiran), Pustaka Baru, Yogyakarta, 2016.

Moeljatno, Perbuatan Pidana dan Pertanggungjawaban Dalam Hukum Pidana, Bina Aksara, Jakarta, 2001.

Muhamad Erwin, S.H., M.H., Hukum Lingkungan Dalam Sistem Kebijaksanaan pembangunan Lingkungan Hidup, Refika Aditama, Bandung, 2009.

Mohammed Nasimul Islam, Water Resource Management Specialist, Asian Development Bank, "Challenges for Sustainable Water Quality Improvement in Developing Countries," presentation in International Water Week, Stockholm, Sweden, September 8, 2010. "M.C. Mehta vs. Union of India," The Enviro-Litigators, Environmental Law and.

Norgaard, Beyond Materialism: A. CoevoluntionaryReinterpretation of the Enviromental Crisis, Review of Soial Economy, 1995.

Philipus M. Hadjon, Perlindungan Hukum Bagi Rakyat Indonesia, Bina Ilmu, Surabaya, 1987

Ivalerina, Feby. "Pendekatan Hukum Administrasi dalam Pengaturan Pencemaran Air".

Kementerian Lingkungan Hidup dan Kehutanan, Standard Operating ProcedurePengawasan Penaatan Perizinan dan Peraturan Perundang-Undangan PengelolaanLingkungan Hidup. Jakarta: KLHK, 2015.

Richard Helmer dan Ivanildo Hespanhol, United Nations Environmental Program, Water Pollution Control - A Guide to the Use of Water Quality Management Principle (London: Thomson Science \& Professional, 1997)

Satjipto Rahardjo, Ilmu Hukum, Aditya Bakti, Bandung, 1991.

Salman, Otje dan Eddy Damian. "Konsep-konsep Hukum dalam Pembangunan.” Ed. 1, Alumni, Bandung, 2002

Sembiring, Raynaldo. "Kinerja BLH Daerah dalam Pengendalian Pencemran, Pengawasandan Penegakan Hukum terhadap Industri yang Berpotensi MencemariDAS Deli." 
Sedarmayanti, Good Governance (Kepemerintahan yang Baik) Dalam Rangka Otonomi Daerah. Bandung, Mandar Maju, 2003.

Silalahi, Daud. "Hukum Lingkungan Dalam Sistem Penegakan Hukum Lingkungan Indonesia" Edisi 2, Alumni, Bandung, 1996.

Siti Sundari Rangkuti, Hukum Lingkungan dan Kebijaksanaan Lingkungan Nasional, Airlngga University Press, Surabaya, 1996.

St. Munadjat Danusaputro, dalam Teguh Sulistia dan Aria Zurnetti, 2011, Hukum Pidana Horizon Baru Pasca Reformasi, PT RajaGrafindo Persada, Jakarta.

Subagiyo, HeNKRI (ed.), Anotasi Undang-Undang Nomor 32 Tahun 2009 tentangPerlindungan dan Pengelolaan Lingkungan Hidup. Jakarta: ICEL, 2014.

Sudharto P. Hadi, Dimensi Lingkungan Perencanaan Pembangunan, Gajah Mada University Press, Yogyakarta, 2005.

Thornton, Justine \& Silas Beckwith, "Environmental Law" 2 nd Edition, Sweet \& Maxwell, London, 2004.

Wibisana, Andri Gunawan. "PROPER dan Penegakan Hukum: Kritik atas ImplementasiPeringkat Lingkungan (Environmental Rating) di Indonesia."

Wardhana, Wisnu Aria, 1995, Dampak Pencemaran Lingkungan, Penerbit Andi OffsetJogyakarta, Jogyakarta.

Wibisana, Andri Gunawan, and Deni Bram. "Penegakan Hukum vs Penataan Sukarela:Analisa Kritis atas Pelaksanaan PROPER.” Edited by Amirudin Dajaan (dkk.)Imami. Perkembangan Hukum Lingkungan Kini dan Masa Depan: ProsidingSeminar Nasional \& KongresPembina Hukum Lingkungan se-Indonesia. Bandung:Bagian Hukum dan Perkembangan Masyarakat FH Unpad, 2013.

Yusuf, Asep Warlan. "Penegakan Hukum Administrasi Lingkungan".

\section{LEGISLATION}

-Law Number 11 of 1974 concerning Irrigation.

- Law Number 5 Year 1990 concerning Conservation of Natural Resources and the Ecosystem.

- Law Number 32 of 2009 concerning Environmental Protection and Management.

- Government Regulation Number 82 of 2001 concerning Management of Water Quality and Water Pollution Control.

- Government Regulation Number 27 of 2012 concerning Environmental Permits.

- Regulation of the Minister of Environment of the Republic of Indonesia Number 13 of 2007 concerning Requirements and Procedures for Managing Wastewater for Upstream Oil and Gas Businesses and / or Activities as well as Geothermal Ways by Injection

- Regulation of the Minister of Environment of the Republic of Indonesia

- Number 1 of 2010 concerning Management of Water Pollution Control.

- Regulation of the Minister of Environment Number 11 of 2012 concerning Guidelines for Criminal Investigation in the Field of Environmental Protection and Management.

- Regulation of the Minister of Environment of the Republic of Indonesia Number 03 Guidebook for Supervision \& Law Enforcement in Water Pollution 